\title{
Spectroscopic and Electrochemical Studies on the Interaction of Epirubicin with Fish Sperm DNA
}

\author{
R. HAJIAN ${ }^{1 *}$, E. EKHLASI ${ }^{2}$ AND R. DANESHVAR ${ }^{3}$ \\ ${ }^{1}$ Young Researchers Club, Gachsaran Branch, Islamic Azad University, Gachsaran, Iran \\ ${ }^{2}$ Gachsaran Branch, Islamic Azad University, Gachsaran, Iran \\ ${ }^{3}$ Department of Applied Chemistry, Darab Branch, Islamic Azad University, Darab, Iran \\ hajian@iaug.ac.ir
}

Received 31 October 2011; Accepted 16 January 2012

\begin{abstract}
The interactions between epirubicin (EPR) and double stranded DNA (ds-DNA) have been studied by UV-Vis spectrophotometry, cyclic voltammetry, fluorescence spectroscopy and viscometery. The apparent binding constant of epirubicin with DNA was found to be $3.8 \times 10^{5} \mathrm{~mol}^{-1} \mathrm{~L}$ and was studied at different temperatures. It indicated that the former method could be successfully applied to the determination of epirubicin. Also, the voltammetric behavior of EPR was investigated at glassy carbon electrode using cyclic voltammetry. Thermodynamic parameters including $\Delta \mathrm{H}^{0}, \Delta \mathrm{G}^{0}$ and $\Delta \mathrm{S}^{0}$ were determined as $-5.7 \times 10^{4},-3.13 \times 10^{4} \mathrm{~J} \mathrm{~mol}^{-1}$ and $-87.96 \mathrm{~J} \mathrm{~mol}^{-1} \mathrm{~K}^{-1}$ respectively. One indication of the strong interaction between DNA and EP was increasing of viscosity. The diffusion coefficients of EP in the absence $\left(\mathrm{D}_{0}\right)_{\mathrm{f}}$ and presence of ds-DNA $\left(\mathrm{D}_{\mathrm{o}}\right)_{\mathrm{b}}$ was calculated as $5.04 \times 10^{-6}$ and $1.13 \times 10^{-6}$ $\mathrm{Cm}^{2} \mathrm{~s}^{-1}$ respectively. According to the thermodynamic parameters, the main binding force could be judged. The experimental results revealed that EPR and ds-DNA had strong interactions. The mechanism of quenching belonged to static quenching and the main sort of binding force was intercalation.
\end{abstract}

Keywords: Epirubicin, Anticancer drug, Spectrophotometry, Spectrofluorometry, ds-DNA, Intercalation.

\section{Introduction}

Advanced breast cancer is an incurable disease and, even if many active antineoplastic agents are available, the aim of the treatment, at present, can be only palliation. Nevertheless, availability of these agents allows us to control the disease for long periods of time and to improve the quality of life in the majority of patients. A prolongation of survival, on the contrary, can be hypothesized only in a minority of cases achieving a complete response with currently available first-line treatments, expected response rates range from 50 to $70 \%{ }^{1-5}$. 
Anthracyclines are widely used in combination schedules and are considered the most effective drugs in the treatment of metastatic breast cancer. Epirubicin (Fig. 1) is an anthracycline drug used for chemotherapy. Epirubicin is favoured over doxorubicin, the most popular anthracycline, in some chemotherapy regimens as it appears to cause fewer side-effects. Epirubicin has a different spatial orientation of the hydroxyl group at the 4' carbon of the sugar, which may account for its faster elimination and reduced toxicity. Epirubicin is primarily used against breast and ovarian cancer, gastric cancer, lung cancer, and lymphomas.<smiles>COc1cccc2c1C(=O)c1c(O)c3c(c(O)c1C2=O)C[C@@](O)(C(=O)CO)C[C@@H]3OC1CC2OC(CO)(C2=O)C(N)C1</smiles>

Figure 1. Chemical structure of epirubicin.

DNA plays a major role in the life process because it carries heritage information and instructs the biological synthesis of proteins and enzyme through the process of replication and transcription of genetic information. DNA is quite often the main cellular target for studies with smaller molecules of biological importance like carcinogens, steroids and several classes of drugs. The investigation of drug-DNA interactions is of current general interest and importance, ${ }^{6-8}$ especially for the designing of new DNA-targeted drugs and the screening of these in vitro.

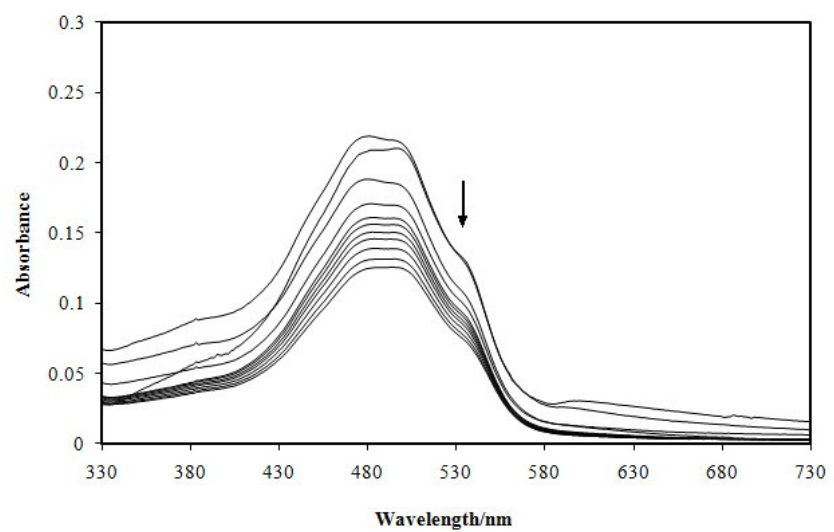

Figure 2. Absorption spectra of EPR in the presence of DNA at different concentrations. $C_{\mathrm{DNA}}=0.0,6.5,12.5,18.0,23.0,27.6,33.2,35.8,39.5,42.9$ and $46.0 \mu \mathrm{mol} \mathrm{L}{ }^{-1}$ for curves 1 11 , and $C_{\mathrm{EPR}}=10.0 \mu \mathrm{mol} \mathrm{L}^{-1}$ in phosphate buffer $\left(0.1 \mathrm{~mol} \mathrm{~L}^{-1}, \mathrm{pH} 7.4\right)$.

In the current work, double stranded fish sperm DNA has selected as the ds-DNA model because of its low cost, ready availability, ligand-binding properties, and all the results of 
the study are consistent with the fact that fish sperm and human DNAs are homologous. The investigation of DNA-EPR binding can provide information of the structural features which determine the therapeutic affectivity of drugs. Interactions with DNA could also be of critical for understanding the drug toxicity and its distribution in the organism. It has been an interesting research field in life science, chemistry and clinical medicine ${ }^{9,10}$.

In previous studies with doxorubicin, ${ }^{11}$ and its analogues daunorubicin ${ }^{12}$ and amoxicillin, ${ }^{13}$ the interaction between these compounds and ds-DNA was studied in aqueous medium by using spectrophotometry and cyclic voltammetry.

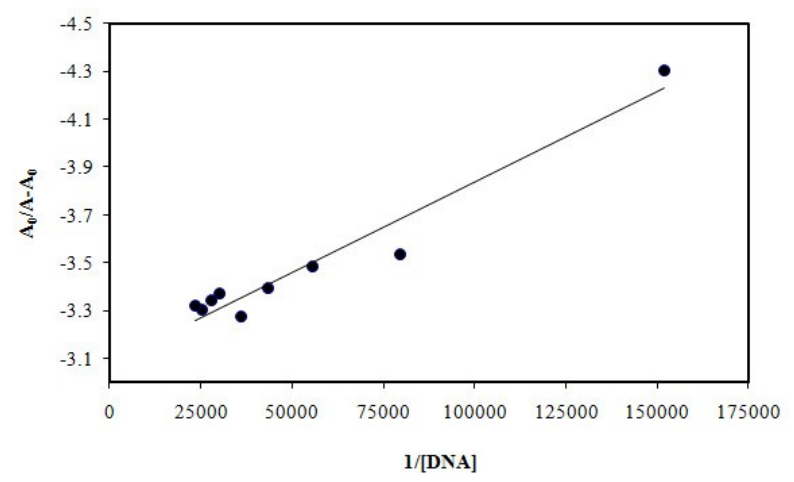

Figure 3. Plot of $A_{0} /\left(A-A_{0}\right)$ versus $1 /[D N A]$ for EPR-DNA system at $360 \mathrm{~nm}$ in $293 \mathrm{~K}(\mathrm{~A})$ and $313 \mathrm{~K}$ (B). Conditions: phosphate buffer $\left(0.1 \mathrm{~mol} \mathrm{~L}^{-1}, \mathrm{pH} 7.4\right), C_{\mathrm{EPR}}=10.0 \mu \mathrm{mol} \mathrm{L}^{-1}$, $C_{\mathrm{DNA}}=6.5,12.5,18.0,23.0,27.6,33.2,35.8,39.5$ and $42.9 \mu \mathrm{mol} \mathrm{L}^{-1}$.

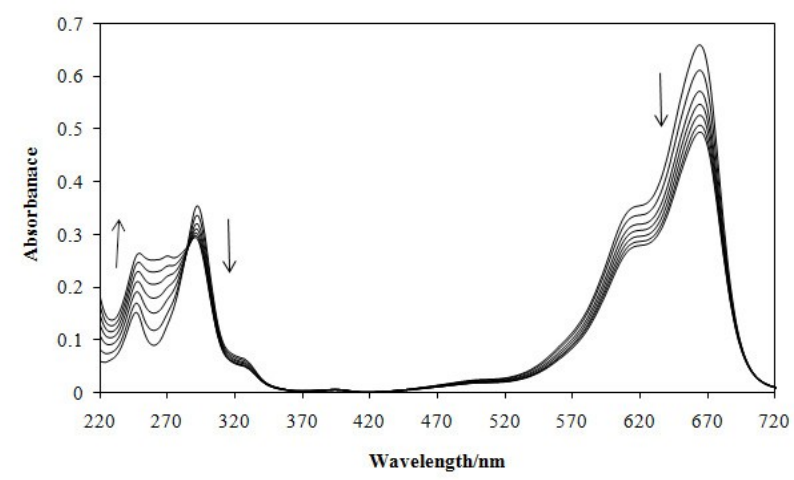

Figure 4. Absorption spectra of $\mathrm{MB}$ in the presence of DNA at different concentrations. $C_{\mathrm{DNA}}=0.0,5.3,10.0,14.8,19.1,23.0$ and $26.7 \mu \mathrm{mol} \mathrm{L}{ }^{-1}$ for curves $1-7$, and $C_{\mathrm{MB}}=100.0$ $\mu \mathrm{mol} \mathrm{L}{ }^{-1}$ in phosphate buffer $\left(0.1 \mathrm{~mol} \mathrm{~L}^{-1}, \mathrm{pH} 7.4\right)$.

As yet there has been no literature report for EPR in connection with DNA by spectroscopy. Accordingly, in this study, we studied the EPR-DNA interaction in combination with cyclic voltammetry (CV), spectrofluorometry, viscometery and specially UV-Vis spectrophotometry. The features of the method have discussed, and results have compared with those methods previously reported for other compounds. 


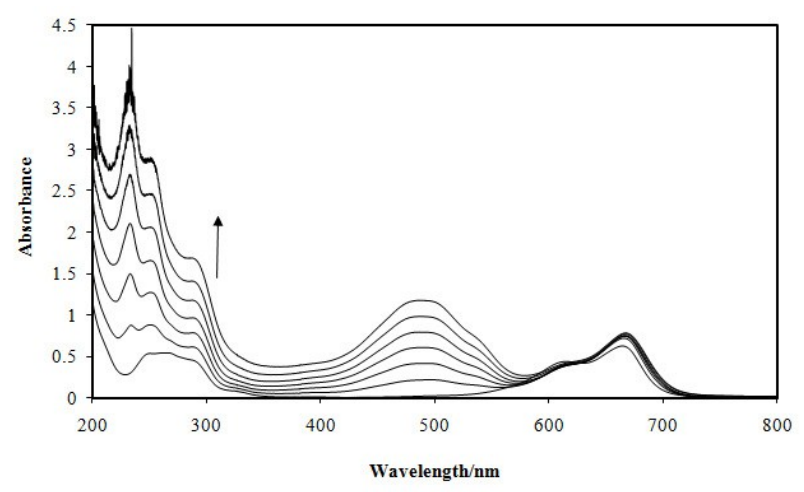

Figure 5. Absorption spectra of the competitive reaction between EPR and MB-DNA. $C_{\mathrm{EPR}}=0.0,10.0,20.0,30.0,40.0$ and $50.0 \mu \mathrm{mol} \mathrm{L}^{-1}$ for curves $1-6, C_{\mathrm{MB}}=10.0 \mu \mathrm{mol} \mathrm{L}^{-1}$ and $C_{\mathrm{DNA}}=50.0 \mu \mathrm{mol} \mathrm{L}-1$ in phosphate buffer $\left(0.1 \mathrm{~mol} \mathrm{~L}^{-1}, \mathrm{pH} 7.4\right)$.

\section{Experimental}

\section{Chemicals}

Calf thymus DNA (Sigma Chem. Co., USA) was used without further purification, and its stock solution was prepared by dissolving an appropriate amount of DNA in doubly distilled water and stored at $4{ }^{\circ} \mathrm{C}$. The concentration of DNA in stock solution was determined by UV absorption at $260 \mathrm{~nm}$ using a molar absorption coefficient $\varepsilon_{260}=6600 \mathrm{Lmol}^{-1} \mathrm{~cm}^{-1}$. Purity of the DNA was checked by monitoring the ratio of the absorbance at $260 \mathrm{~nm}$ to that at $280 \mathrm{~nm}$. The solution gave a ratio of $>1.8$ at $\mathrm{A}_{260} / \mathrm{A}_{280}$, which indicates that DNA was sufficiently free from protein. ${ }^{14}$ The working solution of epirubicin hydrochloride (Couple Inc., Italy) was $2 \mathrm{mg} \mathrm{mL}^{-1}$. Methylene blue (MB) stock solution $\left(1.0 \times 10^{-3} \mathrm{~mol} \mathrm{~L}^{-1}\right)$ was prepared by dissolving its crystals (Sigma Chem. Co., USA) in doubly distilled water and stored in a cool and dark place. All the solutions were adjusted with the Britton Robinson buffer (BR) solution ( $\left.0.1 \mathrm{~mol} \mathrm{~L}^{-1}, \mathrm{pH} 7.4\right)$. All chemicals were of analytical reagent grade, and doubly distilled water was used throughout.

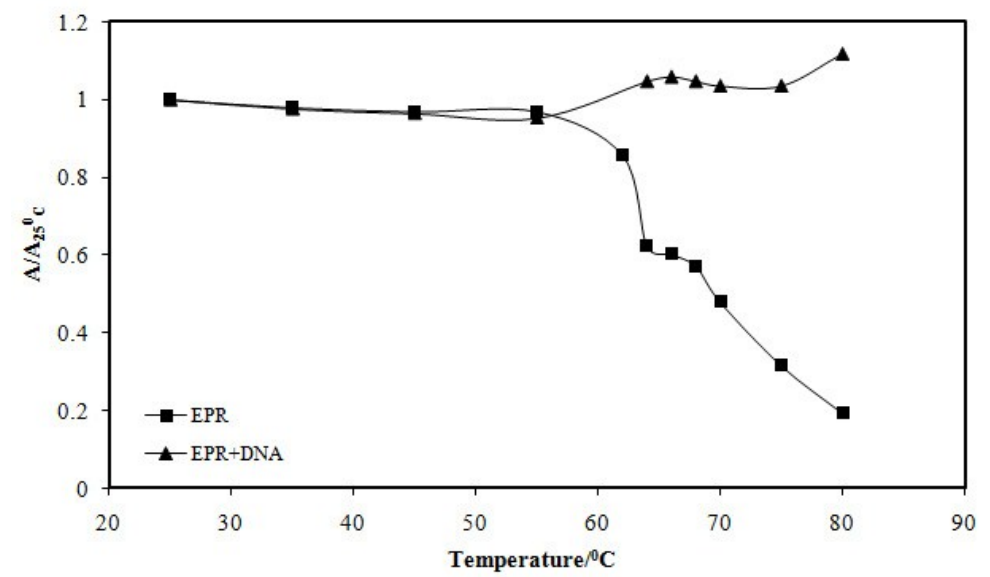

Figure 6. Melting curves for EPR in the absence and presence of ds-DNA at wavelength $482 \mathrm{~nm} . C_{\mathrm{EPR}}=10.0 \mu \mathrm{mol} \mathrm{L}{ }^{-1}$ and $c_{\mathrm{DNA}}=50.0 \mu \mathrm{mol} \mathrm{L}-1$ in phosphate buffer $\left(0.1 \mathrm{~mol} \mathrm{~L}^{-1}, \mathrm{pH}\right.$ 


\section{Apparatus}

The absorption spectra were measured on a Perkin Elmer Lamda 25 spectrophotometer using a $1.0 \mathrm{~cm}$ cell. Fluorescence spectra were measured on a Cary spectrofluorimeter Model FL-4500 equipped with a $150 \mathrm{~W}$ Xenon lamp and a thermostat bath. The widths of both the excitation slit and emission slit were set at $5.0 \mathrm{~nm}$. $\mathrm{pH}$ measurements were carried out with a 691 digital pH-meter (Metrohm Instrument Co. Ltd., Switzerland) with a combined glass-calomel electrode.

Cyclic voltammetry studies were carried out by Autolab 302 N (Switzerland). The threeelectrode system consisted of a glassy carbon electrode (GCE), an $\mathrm{Ag} / \mathrm{AgCl}$-saturated $\mathrm{KCl}$ reference electrode and a carbon counter electrode. All potentials were referred to the reference electrode. All experiments, unless specified otherwise, were run at room temperature $\left(25 \pm 0.1{ }^{\circ} \mathrm{C}\right)$.

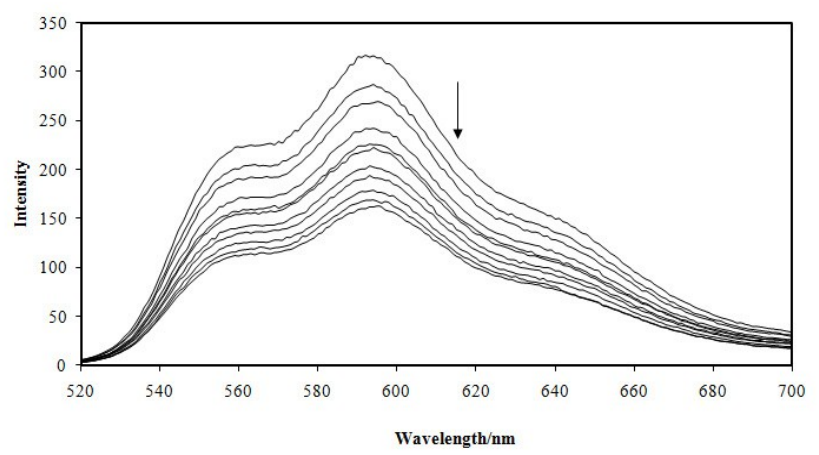

Figure 7. Fluorescence spectra of the EPR in different concentrations of ds-DNA. $C_{\mathrm{DNA}}=0.0,10.0,20.0,30.0,40.0,50.0,60.0,70.0,80.0,90.0$ and $100.0 \mu \mathrm{mol} \mathrm{L}^{-1}$ for curves $1-11$, and $C_{\mathrm{EPR}}=50.0 \mu \mathrm{mol} \mathrm{L}^{-1}$ in phosphate buffer $\left(0.1 \mathrm{~mol} \mathrm{~L}^{-1}, \mathrm{pH} 7.4\right)$ at excitation wavelength of $482 \mathrm{~nm}$.

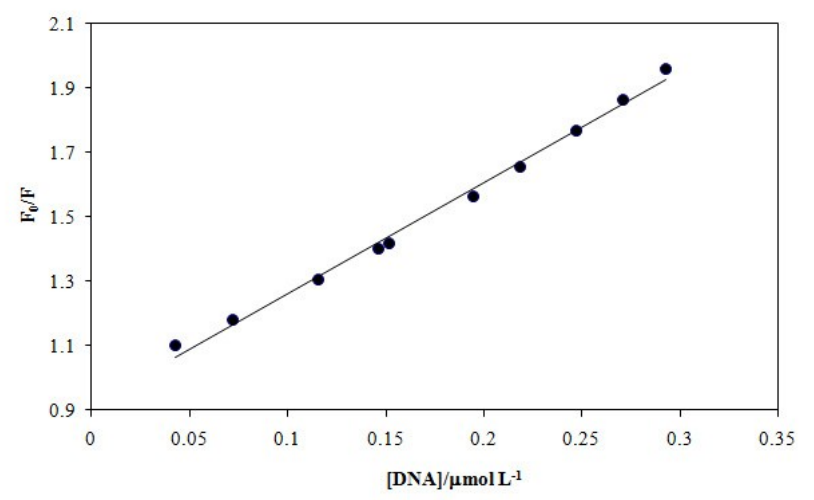

Figure 8. Stern-Volmer plot for the interaction of EPR with DNA. $C_{\mathrm{EPR}}=50.0 \mu \mathrm{mol} \mathrm{L}{ }^{-1}$ in phosphate buffer $\left(0.1 \mathrm{~mol} \mathrm{~L}^{-1}, \mathrm{pH} 7.4\right)$ at excitation wavelength of $482 \mathrm{~nm}$.

Viscosity measurements were performed using a viscometer, which were immersed in a thermostat water-bath at room temperature. Different amount of DNA was then added into the viscometer while keeping the epirubicin concentration constant. The flow times of the samples were repeatedly measured with an accuracy of $\pm 0.20 \mathrm{~s}$ by using a digital stopwatch. 
Flow times were above $250 \mathrm{~s}$, and each point measured was the average of at least three readings. The data were presented as $\left(\eta / \eta_{0}\right)^{1 / 3}$ versus $C_{\mathrm{DNA}}$, where $\eta$ and $\eta_{0}$ are the viscosity of epirubicin in the presence and absence of the DNA, respectively.

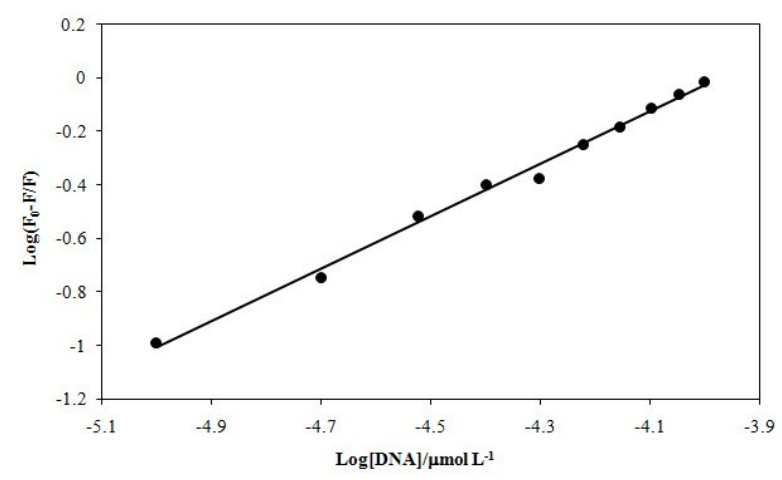

Figure 9. Plot of $\log \left[\left(\mathrm{F}_{0}-\mathrm{F}\right) / \mathrm{F}\right]$ versus $\log [\mathrm{Q}]$ for the interaction of EPR with DNA. $C_{\mathrm{EPR}}=50.0 \mu \mathrm{mol} \mathrm{L}^{-1}$ in phosphate buffer $\left(0.1 \mathrm{~mol} \mathrm{~L}^{-1}, \mathrm{pH} 7.4\right)$ at excitation wavelength of $482 \mathrm{~nm}$.

\section{Results and discussion}

Spectroscopic confirmation on the interaction of EPR with ds-DNA

Spectrophotometric studies

UV - visible spectroscopy is the most common and convenient way to study the interaction between small molecules or rare earth complexes and nucleic acids. Molecules containing aromatic or phosphate chromophore groups can interact with double helix structure of DNA, therefore, the interaction between them can be researched according to changes in the absorption spectra before and after of reaction. For dynamic quenching, the UV-Vis absorption spectrum of a fluorophore is not changed. Only excited-state fluorescencing molecules are influenced by a quencher. But, for static quenching a compound is formed between the ground state of a fluorophore and quencher; consequently, the absorption spectra of a fluorophore should be influenced. ${ }^{15}$

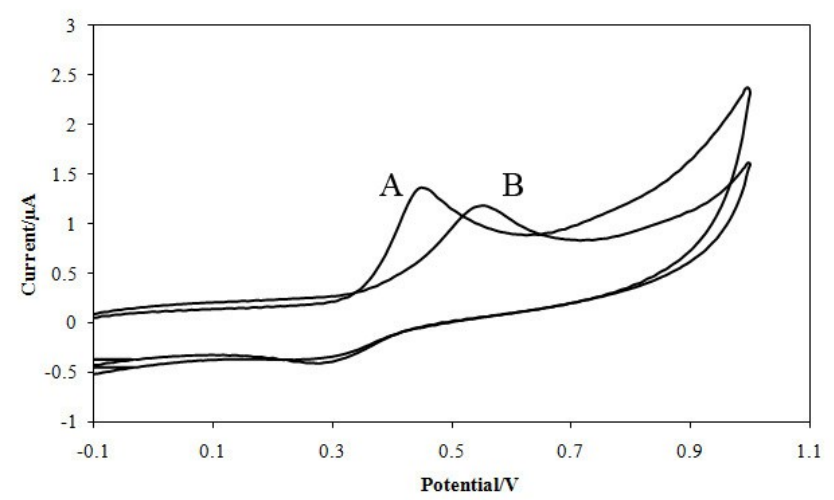

Figure 10. Cyclic voltammetry for EPR in the absence (A) and presence (B) of DNA on the surface of glassy carbon electrode. Conditions: scan rate $=100 \mathrm{mV} \mathrm{s}^{-1}, \mathrm{C}_{\mathrm{EPR}}=10.0 \mu \mathrm{mol} \mathrm{L}{ }^{-1}$, $\mathrm{C}_{\mathrm{DNA}}=13.8 \mu \mathrm{mol} \mathrm{L}^{-1}$, phosphate buffer $\left(0.1 \mathrm{~mol} \mathrm{~L}^{-1}, \mathrm{pH} 7.4\right)$ and potassium chloride $(0.1$ $\left.\mathrm{mol} \mathrm{L}^{-1}\right)$. 
Red shift (or blue shift), hyperchromic (or hypochromic) effects and isochromatic point are spectral properties of DNA-drug interaction, which closely related with the double helix structure. ${ }^{16}$ Generally Hypochromic effect is obvious if the interaction is strong (ex. Intercalation). ${ }^{17,18}$ Wavelength shifting effect is not obvious in the absorption spectra of small molecules if the interaction mode is electrostatic or groove binding.

In order to validate the quenching mechanism, the UV-Vis absorption spectra of EPR and ctDNA were measured (Fig. 2). As seen in Fig. 2, the maximum absorption wavelength of EPR around $506 \mathrm{~nm}$ (curve a) shows a red shift and the absorbance intensity obviously decreases after addition of an appropriate amount of ct-DNA (curves b-k), which indicates that there is an interaction between EPR and ct-DNA. This result reconfirms that the probable fluorescence quenching mechanism of EPR by DNA is a static quenching process.

In order to further study the interaction mode of EPR with DNA, we calculated the binding constant for EPR-DNA at $292 \mathrm{~K}$ and $310 \mathrm{~K}$ according to the double-reciprocal equation: ${ }^{19}$

$$
\frac{\mathrm{A}_{0}}{\mathrm{~A}-\mathrm{A}_{0}}=\frac{\varepsilon_{\mathrm{G}}}{\varepsilon_{\mathrm{H}-\mathrm{G}}-\varepsilon_{\mathrm{G}}}+\frac{\varepsilon_{\mathrm{G}}}{\varepsilon_{\mathrm{H}-\mathrm{G}}-\varepsilon_{\mathrm{G}}} \times \frac{1}{\mathrm{~K}[\mathrm{DNA}]}
$$

Where " $\mathrm{A}_{0}$ " and " $\mathrm{A}$ " are the absorbances of EPR in the absence and presence of DNA, respectively, and $\varepsilon_{G}$ and $\varepsilon_{H-G}$ are their absorption coefficients. The double reciprocal plots of $\mathrm{A}_{0} / \mathrm{A}-\mathrm{A}_{0}$ versus $1 /[\mathrm{DNA}$ ] were linear (at $292 \mathrm{~K}$ and $310 \mathrm{~K}$ respectively) and the binding constants were calculated as $3.85 \times 10^{5}$ and $8.49 \times 10^{4} \mathrm{~mol}^{-1} \mathrm{~L}$ from the ratio of the intercept to the slope equations at 292 and $310 \mathrm{~K}$ respectively (Fig. 3).

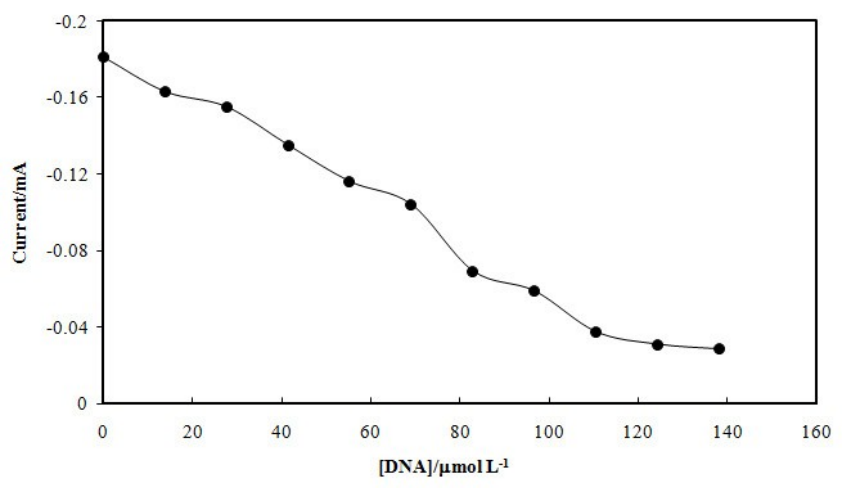

Figure 11. Dependence of cathodic peak current for EPR at different concentrations of DNA. Conditions: $C_{\mathrm{DNA}}=0.0,13.8,27.6,41.5,55.3,69.1,82.9,96.7,110.6,124.4$ and $138.2 \mu \mathrm{mol} \mathrm{L}^{-1}, C_{\mathrm{EPR}}=10.0 \mu \mathrm{mol} \mathrm{L}{ }^{-1}$, Scan rate $=100 \mathrm{mV} \mathrm{s}^{-1}$, phosphate buffer $\left(0.1 \mathrm{~mol} \mathrm{~L}^{-1}\right.$, $\mathrm{pH}$ 7.4) and potassium chloride $\left(0.1 \mathrm{~mol} \mathrm{~L}^{-1}\right)$.

\section{Binding and thermodynamic constants using double-reciprocal method}

The interaction forces between a drug and a biomolecule may involve hydrophobic forces, electrostatic interactions, van der Waals interactions, and hydrogen bonds. Different organic small molecules have different types of interactions toward proteins. The negative value of Gibbs free energy change $(\Delta \mathrm{G})$ reveals that the binding process is spontaneous. Ross et $a l^{20}$ have characterized the sign and magnitude of the thermodynamic parameter, which are associated with various individual kinds of interactions that take place in protein association 
process. A positive $\Delta \mathrm{S}$ value is frequently taken as evidence for hydrophobic interaction. The hydrogen bond interaction between molecules is characterized by a negative $\Delta \mathrm{S}$ value and a negative $\Delta H$ value, and the electrostatic force is characterized by a negative $\Delta H$ value and a positive $\Delta \mathrm{S}$ value. If the temperature does not vary significantly, the enthalpy change $(\Delta \mathrm{H})$ can be regarded as a constant. The free energy change $(\Delta \mathrm{G})$ can be estimated from the following equation, based on the binding constants at different temperatures:

$$
\Delta \mathrm{G}=-\mathrm{RT} \ln \mathrm{K}
$$

$\Delta \mathrm{H}$ and $\Delta \mathrm{S}$ can be calculated from the formulas as follows:

$$
\begin{gathered}
\ln \left(\frac{\mathrm{K}_{2}}{\mathrm{~K}_{1}}\right)=-\frac{\Delta \mathrm{H}}{\mathrm{R}}\left(\frac{1}{\mathrm{~T}_{2}}-\frac{1}{\mathrm{~T}_{1}}\right) \\
\Delta \mathrm{S}=\frac{-(\Delta \mathrm{G}-\Delta \mathrm{H})}{\mathrm{T}}
\end{gathered}
$$

Thermodynamic parameters for the interaction of EPR and ct-DNA were calculated from the thermodynamic functions above (Table 1). The negative value of enthalpy change indicates that the interaction process of EPR with ds-DNA is exothermic. The negative sign for $\Delta \mathrm{G}$ shows that, the interaction process is spontaneous also the negative $\Delta \mathrm{H}$ and $\Delta \mathrm{S}$ values indicated that hydrogen bonding forces might play a major role for the binding of EPR toward DNA.

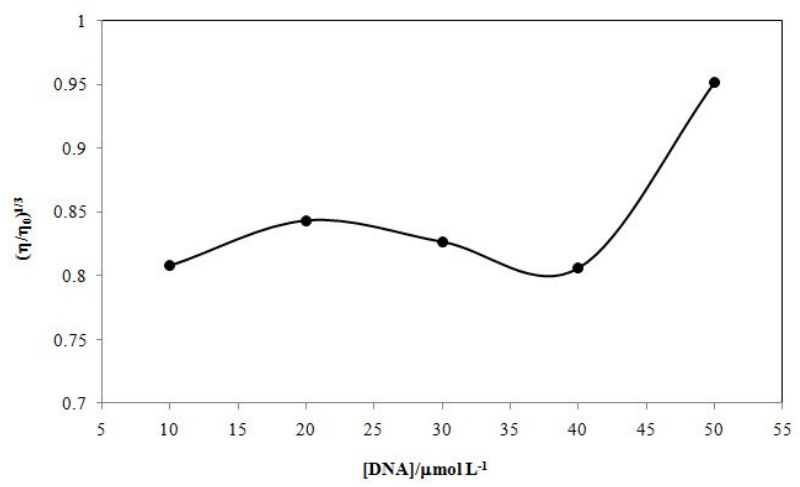

Figure 12. Effect of DNA on the viscosity of EPR solution at $100.0 \mu \mathrm{mol} \mathrm{L}-1 . C_{\mathrm{DNA}}=0.0$, $10.0,20.0,30.0,40.0$ and $50.0 \mu \mathrm{mol} \mathrm{L}^{-1}$ at $298 \mathrm{~K}$, phosphate buffer $\left(0.1 \mathrm{~mol} \mathrm{~L}^{-1}, \mathrm{pH} 7.4\right)$ and potassium chloride $\left(0.1 \mathrm{~mol} \mathrm{~L}^{-1}\right)$.

Table 1. Thermodynamic parameters for the interaction of epirubicin with ds-DNA.

\begin{tabular}{ccccc}
\hline $\mathrm{T}\left({ }^{0} \mathrm{~K}\right)$ & $\mathrm{K}\left(\mathrm{L} \mathrm{mol}^{-1}\right)$ & $\Delta \mathrm{H}^{0}\left(\mathrm{Jmol}^{-1} \mathrm{~K}^{-1}\right)$ & $\Delta \mathrm{S}^{0}\left(\mathrm{~J} \mathrm{~mol}^{-1}\right)$ & $\Delta \mathrm{G}^{0}\left(\mathrm{~J} \mathrm{~mol}^{-1} \mathrm{k}^{-}\right.$ \\
\hline 293 & 385575 & -57071 & -87.96 & -31297 \\
313 & 84926 & & & \\
\hline
\end{tabular}

Interaction of methylene blue with DNA 
Absorption spectra of methylene blue (MB) dye in the absence of DNA ( $\mathrm{pH} 7.4$ ) showed two spectra at maximum wavelengths of 290 and $662 \mathrm{~nm}$ (Fig. 4). These absorptions at two wavelengths gradually decreased with the increasing concentration of ct-DNA and red shift is usually associated with molecular intercalation into the base stack of the ct-DNA. ${ }^{21}$ Those two observed spectral effects were attributed to a strong interaction between the electronic state of the intercalating chromophore and that of the DNA bases. The strength of this electronic interaction is expected to decrease as the third-order of the distance between the chromophore and the DNA bases. ${ }^{22}$ The large observed hypochromism during the interaction of the MB dye with the DNA, strongly suggest that the distance between the intercalated MB dye and the DNA bases is small. Also an isobestic point at $281 \mathrm{~nm}$ demonstrate a new adduct between MB and DNA. The binding constant between MB-DNA at $298 \mathrm{~K}$ according to double-reciprocal equation has determined as $2.80 \times 10^{5} \mathrm{~mol}^{-1} \mathrm{~L}$.

Because of the intercalation between MB and ct-DNA, we used it as a probe for study the competitive interaction of EPR and ct-DNA.

\section{Competitive interaction of EPR with $M B-D N A$}

A competitive interaction between EPR and MB-DNA system was observed by the addition of EPR to a solution containing methylene blue and DNA. As it has clearly shown (Fig. 5), the intensity of MB-DNA spectral band increases significantly at about $662 \mathrm{~nm}$. Also a new peak at $272 \mathrm{~nm}$ appeared which increased progressively in intensity. Addition of different amounts of EPR to MB-DNA solution causes change in the intensity and position of the bands, suggesting that the epirubicin intercalated into the double helix of ds-DNA. ${ }^{23}$

\section{Melting studies}

Heat and alkali can destroy the structure of EPR at the milting temperature (Tm). Interaction of small molecules with DNA can influence on Tm. Intercalation binding can stabilize the molecular structure and $\mathrm{Tm}$ increases above $5-8^{\circ} \mathrm{C}$, but the non-intercalation binding causes no obvious increase in $\mathrm{Tm}^{24}$ The values of Tm for EPR and DNA-EPR system determined, respectively, by monitoring the maximum absorbance values of systems as a function of temperature ranging from $25^{\circ} \mathrm{C}$ to $85^{\circ} \mathrm{C}$. The melting curves have shown in Fig. 6. It can be seen that the Tm of EPR in the absence of DNA is about $55^{\circ} \mathrm{C}$ and decreases continuously by increasing temperature. While the melting curve for EPR-DNA system does not change significantly up to $75^{\circ} \mathrm{C}$.

\section{Fluorescence quenching studies}

On excitation at $482 \mathrm{~nm}$, epirubicin has a strong fluorescence emission peak at $570 \mathrm{~nm}$. Fig. 7 shows the characteristic changes in fluorescence emission spectra during the titration of epirubicin with ds-DNA. The maximum emission intensity of EPR gradually decreased with increasing concentration of ds-DNA, indicated that ds-DNA could quench the intrinsic fluorescence of epirubicin and the binding of EPR to DNA indeed exists.

A variety of molecular interactions can result in quenching, including excited-state reactions, molecular rearrangement, energy transfer, ground-state complex formation, and collisional quenching. Quenching normally refers to nonradiative energy transfer from excited species to other molecules. In fact, two quenching processes are known: static and dynamic. Dynamic quenching refers to a process that the fluorophore and the quencher come into contact during the transient existence of the excited state. Static quenching refers to fluorophore quencher complex formation. 
A quantitative estimation of the quenching in terms of the fluorescence quenching constant was analyzed using the Stern-Volmer Eq. (5): ${ }^{25}$

$$
\frac{\mathrm{F}_{0}}{\mathrm{~F}}=1+\mathrm{K}_{\mathrm{SV}}[\mathrm{Q}]
$$

where $\mathrm{F}_{0}$ and $\mathrm{F}$ are the fluorescence intensities of epirubicin in the absence and presence of the quencher, respectively. $\mathrm{K}_{\mathrm{SV}}$ is the Stern-Volmer dynamic quenching constant and [Q] is the concentration of quencher. Eq. (5) was applied to determine $\mathrm{K}_{\mathrm{SV}}$ by linear regression of a plot of $\mathrm{F}_{0} / \mathrm{F}$ against [Q] (Fig. 8). The value of $\mathrm{K}_{\mathrm{SV}}$ has determined as $3.43 \times 10^{6} \mathrm{Lmol}^{-1}$.

If the static binding reaction between ds-DNA and small molecule happens, and there are the similar and independent binding sites in the DNA, namely, the binding capability of DNA at each binding site is equal. The binding constant $(\mathrm{K})$ and the binding stoichiometry (n) of DNA-epirubicin system can be estimated by the following equation: ${ }^{26,27}$

$$
\log \frac{\mathrm{F}_{0}-\mathrm{F}}{\mathrm{F}}=\log \mathrm{K}+\mathrm{n} \log [\mathrm{Q}]
$$

The values of $K$ and $n$ were obtained from the intercept and the slope of plot $\log [(\mathrm{F} 0-\mathrm{F}) / \mathrm{F}]$ versus $\log [\mathrm{Q}]$ (Fig. 9) as $7.7 \times 10^{3} \mathrm{~L} \mathrm{~mol}^{-1}$ and 0.98 respectively.

\section{Electrochemical studies}

\section{Interaction of epirubicin with DNA}

Cyclic voltammetric studies of EPR at a GCE in BR buffer solutions revealed that the peak potential separations $\Delta E_{\mathrm{p}}=E_{\mathrm{pc}}-E_{\mathrm{pa}}$ are beyond $100 \mathrm{mV}$ indicating an irreversible redox process (Fig. 10). The decrease in peak current of EPR upon the addition of ds-DNA solution is an evidence of drug-DNA interaction. Under these conditions the dramatic changes of CV behavior of epirubicin in the presence of ds-DNA were occurred. When dsDNA is added to a solution of EPR, the cathodic peak current height decreases and shifts from $0.278 \mathrm{~V}$ to more negative values $0.232 \mathrm{~V}$. The cathodic peak current decreased to ca. $15.7 \%$ of those in the presence of ds-DNA (Fig. 11). According to these observations, it seems that the decrease of peak current of EPR after addition of ds-DNA is caused by the intercalation of epirubicin to the bulky, slowly diffusing ds-DNA, which results in considerable decrease in the apparent diffusion coefficient. This is emphasized from the decrease in the slope of the linear $i_{\mathrm{p}}-v^{1 / 2}$ plots $(R \geq 0.9872)$, where the slope values are $2.0 \times 10^{-6}$ and $1.0 \times 10^{-6} \mathrm{~V}^{-1 / 2} \mathrm{~s}^{1 / 2}$ in the absence and presence of ds-DNA respectively. From the Cottrell plots, ${ }^{28}$ the diffusion coefficient $\left(D_{\mathrm{f}}\right)$ of the free epirubicin was found to be $5.4 \times$ $10^{-3} \mathrm{~cm}^{2} \mathrm{~s}^{-1}$, whereas $D_{\mathrm{b}}=1.4 \times 10^{-6} \mathrm{~cm}^{2} \mathrm{~s}^{-1}$ for the bound epirubicin. The changes in current upon addition of ds-DNA can be explained in terms of diffusion of an equilibrium mixture free and bound EPR to the electrode and which can be used to quantify the binding of EPR to ds-DNA. In this context current titrations were performed by keeping the concentration of EPR constant while varying the concentration of DNA using cyclic voltammetry at $\mathrm{pH}$ 7.4.

For the irreversible redox reaction of epirubicin, $\alpha n_{a}$ value $(\alpha$, the electron transfer coefficient; $n_{a}$, the number of electrons involved in the rate-determining step) can be evaluated as 0.45 and 0.49 for free EPR and EPR-DNA adduct based on the slopes of Tafel plots. $^{28}$

\section{Determination of viscosity}

One indication of DNA binding mode is the change in viscosity when a small molecule associates with DNA. Intercalative binding increases the length of DNA and the viscosity significantly, whereas groove binding typically has a smaller effect on viscosity. ${ }^{29}$ Figure 12 reveals that the viscosity of EPR increased considerably by the addition of ds-DNA at concentrations more than $40.0 \mathrm{mmol} \mathrm{L}^{-1}$. It supports the intercalation mechanism between EPR and DNA at high DNA concentrations. 


\section{Conclusion}

The binding interactions of epirubicin as an anticancer drug with ds-DNA in physiological buffer were investigated with UV-Vis, cyclic voltammetry and fluorescence spectroscopic techniques. Absorption spectroscopy studies demonstrated that the binding of EPR to dsDNA is quite strong as indicated by remarkable hypochromicity and equilibrium binding constant $\left(3.85 \times 10^{5} \mathrm{~mol}^{-1} \mathrm{~L}\right)$. A competitive reaction monitored by UV-Vis spectroscopy, between the potential probe, methylene blue (MB) dye, DNA and EPR showed that the intercalated $\mathrm{MB}$ was displaced from the DNA-MB system by the EPR. An intercalation binding of the epirubicin with DNA was supported by the results from DNA melting and viscosity studies. The progress of the intercalation process was investigated by cyclic voltammetry and fluorescence spectroscopy.

\section{Acknowledgement}

The authors gratefully acknowledge the support of this work by Islamic Azad University branch of Gachsaran (IAUG). The assistance of Red Cross Drug Store for providing pure drugs is also gratefully acknowledged.

\section{References}

1. Amiel S A, Stewart J F, Earl H M, Knight R K and Rubens R D, Cancer Chin. Oncol. 1984, 20, 631.

2. Andersson M, Daugaard S, Von Der Maase H and Mouridsen H T, Cancer Treat. Rep. 1986, 70, 1181.

3. Blomqvist C, Elomaa I, Rissanen P, Hietanen P, Nevasaari K and Helle L, Actu. Oncol. 1992, 31, 231.

4. Buzdar A U, Sem Oncol. 1988, 15, 65.

5. Creech R H, Dayal H and Catalan R B, Proc. Am. Sot. Clin. Oncol. 1984, 3,121.

6. Sahoo B K, Ghosh K S, Bera R, Dasgupta S, Chem. Phys. 2008, 351, 163.

7. Sun Y, Bi S Y, Song D Q, Qiao C Y, Mu D and Zhang H Q, Sens. Actuators B: Chem. 2008, 129, 799 .

8. Ling X, Zhong W Y, Huang Q and Ni K Y, J. Photochem. Photobiol. B: Biol. 2008, 93 172.

9. Gray R D and Stroupe S D, J. Biol. Chem. 1978, 253, 4370.

10. Cui F L, Fan J, Li J P and Hu Z D, Bioorg. Med. Chem. 2004, 12, 151.

11. Hajian R, Shams, N and Mohagheghian, M, J. Braz. Chem. Soc. 2009, 20, 1399.

12. Hajian R, Shams N and Parvin A, Chin. J. Chem. 2009, 27, 1055.

13. Hajian R, Shams N and Azarinezhad N, Asian J. Chem. 2010, 22, 8007.

14. Mahadevan S and Palaniandavar M, Inorg. Chem. 1998, 37, 693.

15. Zhang G W, Wang A P, Jiang T and Guo J B, J. Mol. Struct. 2008, 891, 93.

16. Yang P and Zhou C Q, Acta Chim. Sinica. 2003, 61, 1455.

17. Ysoe S A, Baker A D and Strekas, T C, J. Phys. Chem. 1993, 97, 1707.

18. Gao E J, Zhao S M, Liu Q T, and Xu R, Acta Chim. Sinica. 2004, 62, 593.

19. Purcell M, Neault, J F and Riahi T, Biochem Biophys Acta. 2000, 1478, 61.

20. Ross P D and Subramanian S, Biochemistry 1981, 20, 3096.

21. Long, E C and J Barton K, Acc. Chem. Res. 1990, 23, 271.

22. Huang, C Z., Li, Y F and Feng P, Talanta 2001, 55, 321.

23. Ensafi A A, Hajian R and Ebrahimi S, J. Braz. Chem. Soc. 2009, 20, 266.

24. Kumar C V, Turner R S. and Asuncion E H., J. Photochem. Photobiol. A: Chem. 1993, 74, 231.

25. Lakowicz J R., Principles of Fluorescence Spectroscopy, 3rd ed., Springer Publications, New York, 2006.

26. Kashanian S and Dolatabadi J E N, DNA Cell Biol. 2009, 28, 535. 
27. Sun Y T, Bi S Y, Song D Q, Qiao C Y, Mu D and Zhang H Q, Sens. Actuat. B: Chem. 2008, 129, 799.

28. Bard A. J. and Falkner L R, (Second Eds.), Electrochemical methods, Fundamentals and Applications, John Wiley \& Sons, New York, 2000.

29. Breslin D T, Coury J E, Anderson J R, McFail-Isom L, Kan Y Z, Williams L D., Bottomley L A and Schuster G B, J. Am. Chem. Soc. 1997, 119, 5043. 


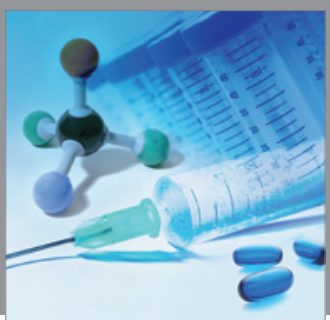

International Journal of

Medicinal Chemistry

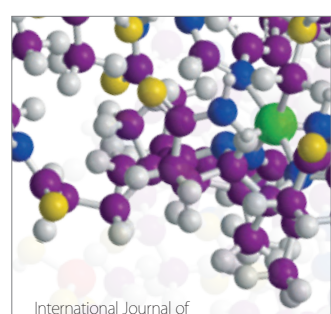

Carbohydrate Chemistry

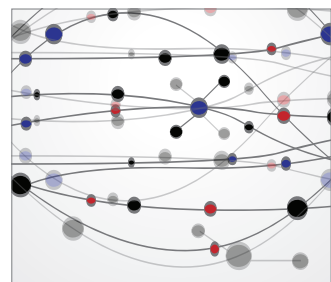

The Scientific World Journal
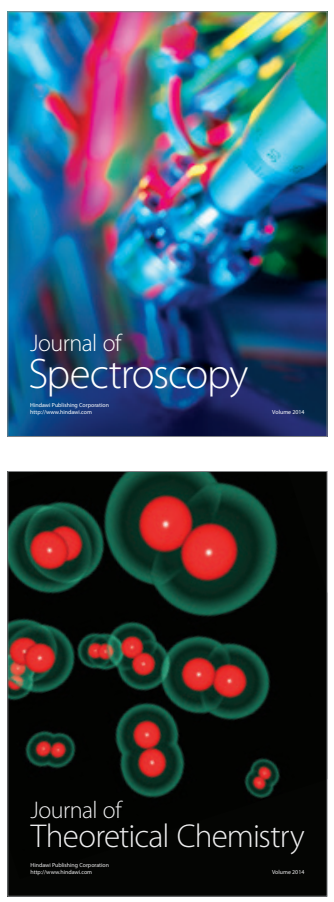
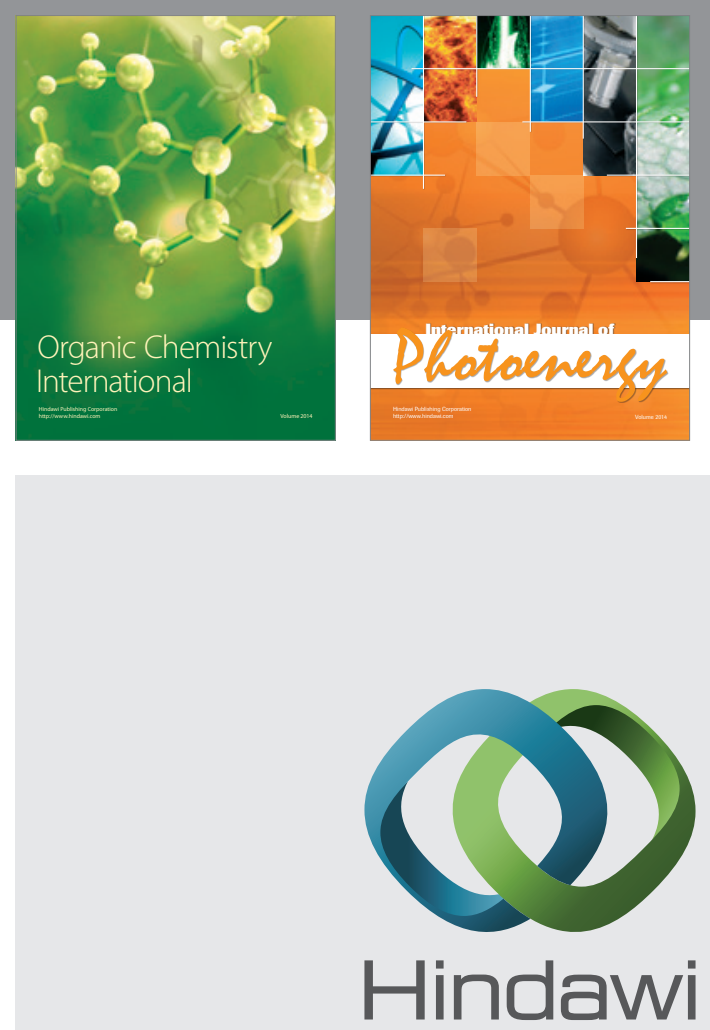

Submit your manuscripts at

http://www.hindawi.com
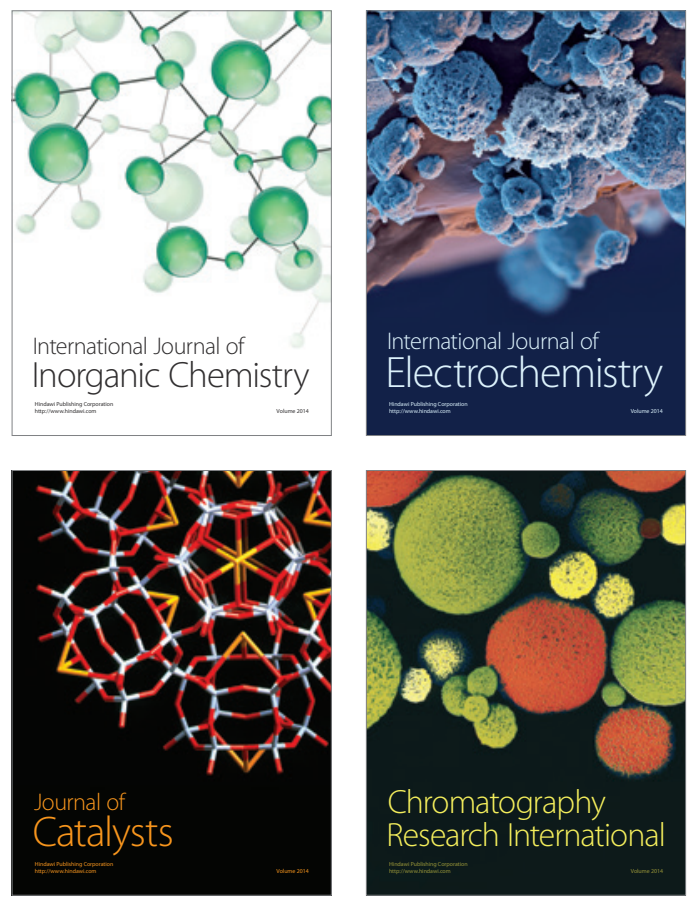
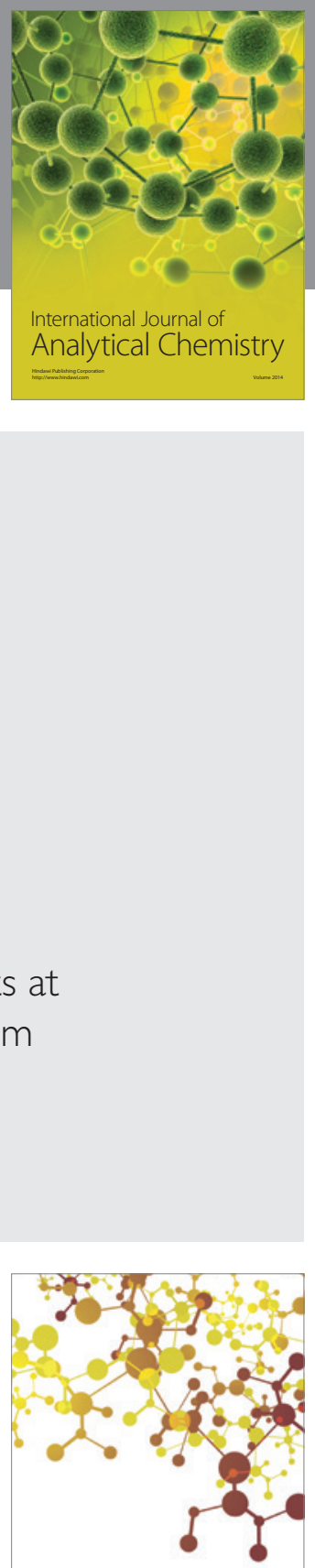

Journal of

Applied Chemistry
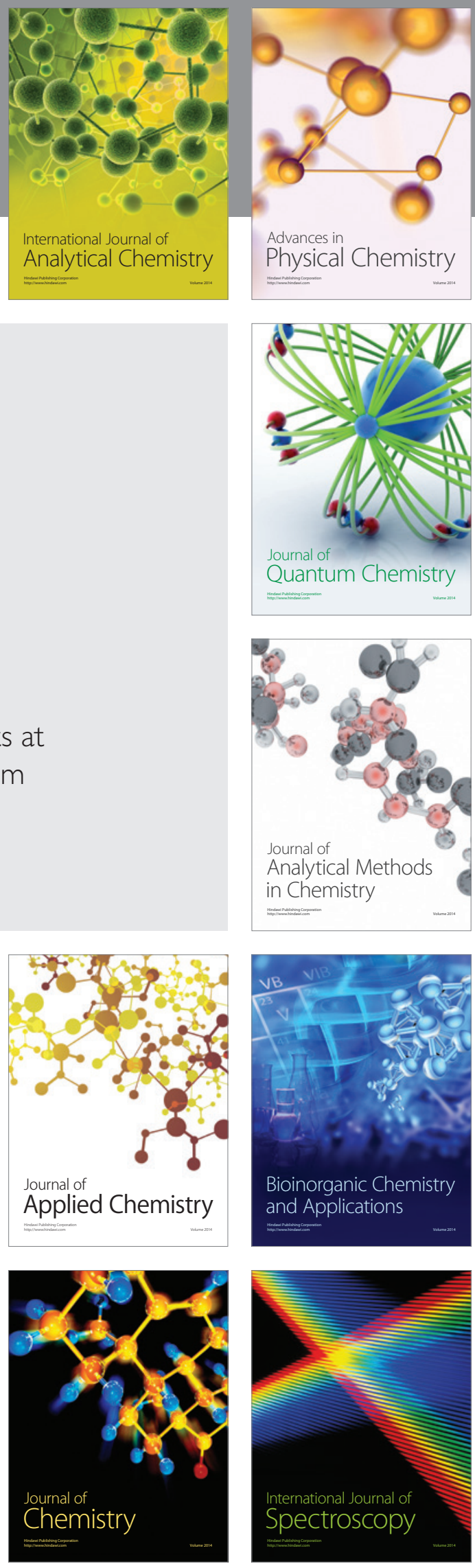